\title{
Victoria Byard
}

\section{Abstract}

In 1948, BBC producer Cecil Madden speculated in the BBC Quarterly about 'where television drama is going, whether it aims to be a photographed stage play, a competitor to the film, or an illustrated broadcast. The truth probably belongs somewhere between them all' (John Caughie, Television Drama: realism, modernism and British culture; Oxford, 2000, 41). Madden's construction of early television drama as an innately hybridised form of media was arguably not borne out of a desire for radical experimentation but, rather, a logical extension of his long-standing association with theatre, show business and television. His motto, 'A play a day,' also suggested his approach to drama as both popular form and part of the foundations of the BBC schedules. Two years later, Madden was made acting Head of the new Children's Programmes department, remaining in post for only eight months before being replaced by Freda Lingstrom. This article will argue that, during the brief period of his administration, Madden's 'expansive' and popular approach to drama significantly influenced the drama output of the Children's Department. It will analyse the form, style and spaces of Puck of Pook's Hill (BBC, 1951), Five Children and It (BBC, 1951) and Man in Armour (BBC, 1951-1954) and situate them within Madden's own explication of television drama as hybridised and spectacular. Using archival research, it will compare the approaches to children's television drama articulated by Madden and Lingstrom and examine how these affect the discourse of children's television within British public service broadcasting.

\section{Correspondence to: Department of History of Art \& Film, University of Leicester, University Road, Leicester LE1 7RH. E-mail: vrb3@le.ac.uk}

'Television drama matters,' avers George Brandt. 'It is an important aspect of the culture of today. It merits critical attention. ${ }^{1}$ The same is true of drama for children, yet, as part of the often already marginalised discourse of children's television, it has received less critical attention, with children's serials and plays from the 1950s having been particularly overlooked. While children's dramas of later decades have benefited from extant recordings and proximity, the earliest have often been overlooked due to their scarcity. The absence of any existing audiovisual material, particularly from the pre-1955 period, makes 'the recovery of the early history of television form and style an archaeological rather than a strictly historical procedure. ${ }^{2}$ Consequently, this article uses archival research from the BBC Written Archive Centre to recover and reassess the early years of BBC children's television drama in the absence of the television serials themselves. The children's drama serials Puck of Pook's Hill and Five Children and It in 1951 and Man in Armour (1951-1954) all originated under Cecil Madden's brief tenure as Acting Head of Children's Programmes. This article uses production and institutional histories to investigate whether these programmes 
created a hybridised and spectacular aesthetic within early children's television drama. In so doing, it attempts to complicate current understandings of early children's drama and Cecil Madden's contribution to its form and aesthetic, and suggests that a reassessment of both might be overdue.

\section{Children's television drama: 1950-1951}

When the BBC Television Service was resurrected after World War II, so too was its children's programming. However, between 1946 and May 1950, when the Children's Programmes department was first instituted, its production was ad hoc, generalised, and confined to a one-hour broadcast on Sundays. Under the supervision of Mary Adams, Head of Television Talks, children's programmes such as Muffin the Mule, other puppet productions, and occasional plays, such as a production of George Bernard Shaw's The Immortal Lady in collaboration with Glyndebourne and the Toynbee Hall Children's Theatre were produced and broadcast, but Adams lobbied vigorously for the development of further scheduling and production, particularly of drama. ${ }^{3}$ However, it was not until Cecil Madden was appointed as Acting Head of Children's Programmes in September 1950 that drama became a consistent, structured and popular component of children's television. ${ }^{4}$

Within a year of its formation, the Children's Programmes department was producing at least 11 drama serials throughout the year, including critically acclaimed productions like The Railway Children (BBC, 1951), and the contemporary press heralded Madden as one of the pioneers of this television seriality. In an article about Children's Programmes 'under the direction of Cecil Madden, one of television's earliest and most inventive programme practitioners,' The Manchester Guardian stated '[a]nother good idea is the television serial, starting on December 12, of "Little Women". Television, one feels, has always offered opportunities for serial stories, and perhaps the Children's Hour will lead the way in showing what can be done. ${ }^{5}$ Little Women was subsequently the first serial on British television, and the production of various other serials for both children's and adult schedules quickly followed. ${ }^{6}$

Despite Madden's contributions to children's television, his tenure as Acting Head of Children's Programmes only lasted eight months. He was displaced, allegedly disappointedly, by the appointment of Freda Lingstrom as Head of Department in April 1951. The Daily Express declared, 'News of the appointment caused surprise among TV executives, for it had been widely assumed that, after eight months in the job, Mr Madden would be confirmed in his appointment. ${ }^{7}$ Madden might have been regarded as a certainty by the press but David Buckingham's historical analysis states that while 'Madden had both expanded the service and centred its output [...] he was viewed with suspicion by the BBC hierarchy as someone with too great a leaning towards 'theatre people' and a dramacentred 'repertory company' approach.' 8 Ironically, Madden's 'leaning' towards light entertainment, regarded with such suspicion by the BBC, had been the foundation of his previous success within the Corporation, producing early show business spectaculars for television such as Here's Looking At You! (BBC, 1936) and later the magazine programme, Picture Play (BBC, 1936-1952). 
Despite these associations, Madden had clearly given some thought to television drama as a developing form. Two years before he was appointed to Children's Programmes, Madden, in an article for the BBC Quarterly, speculated about 'where television drama is going, whether it aims to be a photographed stage play, a competitor to the film, or an illustrated broadcast. The truth probably belongs somewhere between them all.' Citing this article, Caughie describes Madden as "very much more a "television man" than [then BBC Director of Drama] Val Gielgud. ${ }^{\prime 9}$ Madden's considered, hybridised approach to television drama may counter, at least in part, the accusation that he was too invested in light entertainment to be a drama producer, an argument reinforced by documents in the BBC archive in which he attempted to articulate and produce a new canon of children's television drama. This production strategy may, however, suggest an alternative reason for Madden's replacement as Acting Head. His plans for children's drama might have proved too extravagant for the fledgling Television Service and, while his production policy was ambitious, it had an extended and rigid timeline and was rather less well defined than Lingstrom's. 'We began but without time to pursue it,' reported Joanna Spicer, Madden's successor as Programme Organiser, about an exchange with Madden, 'a rather muddled conversation about the importance of deciding the proportion of "entertainment" and "enlightenment" ingredients in Children's Programmes.' 10

However 'muddled' Madden might have been on the balance between educational and entertaining - and the publicised 'hint that the children's programmes are to become "more educational"'11 under Lingstrom might be an indication of where he failed to meet with BBC expectations - he was very clear about drama's importance to Children's Programmes. Spicer's report to the Director of Television continued, 'On the question of the serial dramatization of books, Mr Madden points out that this is pioneering work and that ample time must be given to the staff producing the serials to build the foundations of this activity well.' ${ }^{12}$ An attached document laid out Madden's policy 'for the regular production of series of dramatized books':

A dramatised book serial of eight episodes will take up to two months preparatory work, followed by two months production and a week or so clearing up at the end. Mr Madden states that during this, say, $4 \frac{1}{2}$ months, the producer concerned is not available for any other work. Because of the length of this period, he thinks it wise to devote two people to each serial so that there need be no interruption from illness or other accident. He also believes that both should not be of the same sex. The plan for serials therefore imposes a pattern on the employment of Mr Madden's staff for the year. ${ }^{13}$

Drama production might have benefited from this structured, segregated approach but it seems that BBC management felt that the Corporation did not. Anna Home cites a memo between Madden and Cecil McGivern in which Madden was 'castigated in no uncertain terms for great extravagance' in requesting studio time, ${ }^{14}$ and the attachment to Spicer's report concluded, 'The programme policy on which Mr Madden has embarked, for the regular production of series of dramatized books, puts a heavy strain on the production group.' ${ }^{15}$ Clearly, this production policy took up a lot of man-hours and studio time that might otherwise have been used, and Madden appears not to have been able to institute it before he was replaced by Lingstrom. 
Despite this, it was under Madden's 'pioneering' tenure that the three drama serials upon which this article focuses began production. These expansive, hybridized productions with distinct elements of 'showmanship' and spectacle go some way to extending Jacobs' deconstruction of early television drama as 'static and theatrical' ${ }^{16}$ to 1950 s programming for children and suggest that a reappraisal of early television drama for children, and Madden's influence upon its form and scheduling, is due. However, the recovery of early television form and style through production histories also problematises Madden's alleged predisposition towards theatre and show business, suggesting that while hybridisation in media and aesthetic advanced children's television drama significantly under Madden, it also had the potential to vitiate (or be perceived to vitiate) BBC public service values and the protectionist sphere of BBC children's television.

\section{Puck of Pook's Hill (BBC, 1951)}

Puck of Pook's Hill, adapted from Rudyard Kipling's novel into a six-episode serial, was transmitted live in September and October 1951 from Studio D in Lime Grove, but production began in March of that year, a month before Madden's departure. The production file reveals that, from scripting to transmission, Puck of Pook's Hill took approximately eight months to make; far longer than the four and a half months that Madden had suggested his dramatised serial productions would take. ${ }^{17}$ Production may have been delayed, however, by the departure of Madden and the institution of Lingstrom from May 1951, as it also delayed the production of Five Children and It. A month prior to his departure, Madden contacted the producer Matthew Forsyth to discuss the production, which he described as 'a very interesting idea,' although he suggested it might run into the problems which haunted those producing children's television:

One of the great troubles of Children's Television is the lack of advance rehearsal on the floor and the fact that rehearsals have to end at 4 p.m., which makes for very little time with the cameras. ${ }^{18}$

Madden ended on a more encouraging note: 'If you feel these points can be overcome and scripts simplified, by all means let's discuss the matter further. ${ }^{19}$ As a department Head, Madden was clearly aware of, and involved with, the production of children's drama under his administration, despite its problems.

In Puck of Pook's Hill, Puck, 'the oldest Old thing in England,' shows children, Dan and Una, the history of England by invoking characters and major events from previous centuries. Forsyth's production recreated English history and landscape in studio using a three-camera set-up, but used specially filmed telecine inserts as well as library stock to expand the drama and to create the fantastic. ${ }^{20}$ Location filming for the second episode took place on 20 and 21 September 1951 at Myms Wash, Middlesex. ${ }^{21}$ Telecine scripts for this episode show four separate sequences to be shot of the children's first encounter with Sir Richard, Richard and Dan's conversation whilst on horseback, Richard's combat with Hugh and a shot exterior to Lime Grove of an elderly Richard, making them fairly extensive within a 30-minute episode. This, in addition to library footage, suggests that while it is impossible to judge average shot 
length in the absence of studio scripts or extant footage, Puck may have been a relatively mobile and hybridised production, much in the vein of Madden's vision of television drama.

The spectacle and hybridity of Puck of Pook's Hill were reinforced by the designs of Lawrence Broadhouse. His elaborate designs created both mise-en-scène, through sets for medieval castles, open moorlands and Roman camps down to the legion's signum, and models and in-studio visual effects, which were used to create the illusion of smoke signals being sent across moorland. Broadhouse built a tabletop miniature of the landscape in planed perspective, and smoke effects were fed through at different depths within the model and filmed with a slow motion film camera. ${ }^{22}$ However, the discourses of media hybridisation and the spectacular, which were evident in the production's aesthetic and form, were reinforced elsewhere. Not only did Puck of Pook's Hill reflect Madden's concept of a composite media text, it also featured 'Wee' Georgie Brown in the starring role. Georgie Brown was a well-known, long-standing variety artist who, as a small person, specialized in playing schoolchildren in a music hall act. Brown appeared in Puck as a childsized adult, both countering and reinforcing the associations of spectacularity, show business and the uncanny inherent in his previous music hall roles. Wood's fame may, however, have come with its own problems. One of the key costs in an already expensive production was Wood's fee which, at $£ 63$, was nearly three times the amount received by any other performer, ${ }^{23}$ but, in light of telegrams in the production file which indicate that Madden negotiated personally with Wood, it seems likely that Madden was aware of this transaction and approved it. ${ }^{24}$

Under Madden's influence, Puck of Pook's Hill was a hybrid production with strong associations with theatrical 'show business' and an aesthetic that constructed drama as inter-mediated and spectacular. While it used elements of theatre, such as elaborate studio sets and the casting of 'Wee' Georgie Wood as Puck, it also deliberately attempted to suture together and more importantly into each other live studio transmission and other intermedia elements, such as extensive film shooting, model miniatures and physical effects, to create a complex televisual text.

\section{Five Children and It (BBC, 1951)}

Five Children and It, an adaptation of E. Nesbit's children's classic in which five Edwardian children discover a Psammead who can grant wishes, was, like Puck of Pook's Hill, oriented around the fantastic. Although it was transmitted under Freda Lingstrom's administration just as Puck had been, it nevertheless fits into the schema of early children's television drama under Madden as a television production with a spectacular and hybridised narrative and aesthetic and associations with theatricality. Produced by Dorothea Brooking, only just beginning her illustrious career in children's television drama in 1951, the drama was shown as a two-part serial on Sunday 17 and 24 June $1951 .{ }^{25}$

The production history opens with the arrangements for an extensive flying sequence created through suturing telecine material shot on location into studio shots; while the sequence itself was shown in the first episode, the cost was defrayed against the entire serial. ${ }^{26}$ The fantastic and spectacular therefore not only constituted the aesthetic of the serial but also a significant part of the $f 500$ budget, and contemporary press reports suggest 
that genre was identified as a potential attraction for viewers. The Manchester Guardian reported, 'Dorothea Brooking [...] will produce on Sunday and on June 24 a two-part version of Five Children and It, another story by Mrs Nesbit which has an element of fantasy and which should be interesting to handle on television. ${ }^{27}$

Brooking handled the element of fantasy through a complex spectacle of media hybridity, editing together film inserts, studio filming, and theatrical effects, most notably to create the illusion that the children have been given the ability to fly. In a letter dated April 1951, Brooking stated that she had asked Anthony de Lotbiniere, a film editor on Children's Newsreel and previously a BBC Assistant Film Librarian, 'if he knew of any stock library shots of countryside taken from the air.' De Lotbiniere suggested that if the production could charter a helicopter, they could create the film themselves and consequently make the spectacular a deliberate and particularised element of the serial. ${ }^{28}$ Charles Gardner, the $B B C$ 's Air Correspondent, subsequently advised Brooking

British European Airways think that it will be quite easy to fix up your helicopter filming [...] Some time in May I expect that Television Newsreel will be flying along the route in the helicopter to get shots for release when the service opens on June 1st. I should think that whoever covers this story for TV Newsreel could probably also shoot your requirements during the journey. This is merely a suggestion and I'm sure that if you want a special flight B.E.A. can fix it. ${ }^{29}$

Brooking decided on a special flight so that 'the helicopter could hover over the church tower, which would enable us to cut into the film studio shot of the children actually flying down on to it. ${ }^{\prime 30}$ To achieve this film studio shot, Brooking negotiated with Kirby's Flying Ballets company, 'Producer of Peter Pan Flying Effects, Somersaulting [sic], Diving \& Auditorium Flying,' to provide four 'solo machines,' more usually used in theatres. ${ }^{31}$ These were temporarily installed inLime Grove so that the child performers could simulate flight for filming within the studio. Brooking thereby produced an extensive filmed sequence, both on location and in studio, which worked syncretically to produce the illusion that the children had flown across the English countryside only to become stranded at the top of a church tower.

Production documents make clear Brooking's desire to create and transmit a convincing, composite flying sequence; however, through institutional synergy and the dedicated, innovative approach of the production team, the sequence developed into a collage of instudio visual effects and dedicated aerial photography film to create a hybridised spectacle. The filming sequence was interlaced more securely through the designs of Lawrence Broadhouse, once again contributing to the aesthetic and form of children's drama production under Madden. His instructions for this sequence required two sets: the first, for the children's take-off, was a basic grassy bank with a skycloth in the background but the second, in which the children would 'land,' called for a church tower set, backed by a skycloth, and surrounded by treetops. For this, Broadhouse suggested that the studio floor be covered by 'a net suspended horizontally about 6" above floor with the greenery laid on it and stuck into it.' ${ }^{32}$ 
BBC inter-departmental collaboration and the 'pioneering' ethos Madden identified for drama production, as well as production staff committed to innovation in editing, form and aesthetic, gave Brooking the opportunity to create a truly fantastic journey. It also allowed Madden to establish the 'foundations' of a canon of children's television drama which combined seriality, spectacle and hybridity.

\section{Man in Armour (BBC, 1951-1954)}

Unlike Puck of Pook's Hill and Five Children and It, Man in Armour was an original drama serial. Written by Godfrey Harrison and produced by Rex Tucker in 1951, the response to the first series was not critically overwhelming: C.A. Lejeune described it as having too much helter-skelter and too little story, ${ }^{33}$ and Joanna Spicer as having 'a flavour ... of charade. ${ }^{34}$ However, it was popular enough to produce two further series: one in 1952, produced by Vivian Milroy, and another in 1954, produced by Shaun Sutton. The production differences between series provide an interesting reading of how production strategy may have changed under Lingstrom, most significantly in terms of budget. However, like Puck of Pook's Hill and Five Children and It, Man in Armour was also situated around show business and hybridity, although in origin more than aesthetic, an association that persisted into the later series and caused long-standing problems.

Man in Armour starred Bruce Gordon as 'the shy and retiring Sir Archibald Willow whose singular fortune or misfortune it has been to be the possessor of a suit of armour which has the effect of keeping him alive or at least preserved for five hundred years.' ${ }^{35}$ Sir Archibald was pursued by his equally long-lived enemy, Sappho the Wizard. While Man in Armour was, compared to the other two serials, less immediately inter-mediated and more studiobound, it still used extensive film inserts to create the fantastic and expand drama. Sappho's tricks were, in the 1952 production at least, created through film, not solely via the insert but as deliberately shot elements of mixes. Through the use of superimposition and filmed mixes, the production was able to construct itself generically, creating the televisual illusion of people and objects appearing and disappearing. ${ }^{36}$

This was reinforced by a design aesthetic which was, apparently, relatively expansive, at least for the first series; the production using up to five or six sets per episode. Under Lingstrom's administration, however, Harrison was being urged to write scripts for three or four sets at most, and costs were continually being urged downwards. By 1954, Sutton seems to have been reduced to creating the fantastic through the use of stock props, including ' 1 stuffed black cat,' ' 1 stuffed dragon-type lizard,' and '1 human skull,' and stock sound effects, sets, and costumes. ${ }^{37}$ Film inserts for the 1954 series were now in terms of seconds rather than minutes and were also mostly stock, augmented by the use of dry ice and 'flash powder.' ${ }^{38}$ However, these budget reductions may be attributed as much to Madden's association with 'theatre people' as to Lingstrom's focus on economy.

Man in Armour had not in fact originated within the Children's Programmes department. It was brought to Madden as an idea by Harry Dubens, a West End theatrical agent, who then suggested Gordon as the star and Harrison as the writer, both of whom, perhaps unsurprisingly, were on Dubens' client list. While Madden would later defend Man in 
Armour as Dubens' concept, it was perhaps more accurately Dubens' theatrical package designed for Madden's drama output. Even for the third series the BBC was paying Dubens f63 per episode in royalties for Man in Armour. ${ }^{39}$ These close and expensive links between theatre and Man in Armour once again invoked the spectre of Madden, both as a producer whom BBC management suspected of being too close to theatre and show business and a presence still haunting Children's Programmes.

Madden's continuing involvement in Children's Programmes even after his replacement may have resulted from the expectation that upon her appointment Lingstrom would, 'of course, have the advice of Mr Cecil Madden, who up to now has been acting head of the children's television programmes,' but his advice was trenchant. ${ }^{40}$ Within a month of a second series being discussed, Madden contacted Jack Rich, the Children's Programme Organiser, to complain, 'Surely if we are reviving "The Man in Armour" series for Bruce Gordon, starting on 20 December, he should be contracted by now. Both he and Dubens phoned me today to say that he has turned down a tour on the strength of it, but he has no contract from us. ${ }^{41}$ Only two weeks later, Madden protested that Rich and producer Vivian Milroy had been 'high-handed' in not crediting the genesis of Man in Armour to Dubens and that 'Milroy should have in courtesy consulted him in some way, such as on casting.' More strongly, he went on, 'I think you have done your best to murder the series before it begins' through bad scheduling and reduction of episode length. An annotation by Rich asked Lingstrom

May I please have your guidance about this? He obviously feels very upset and I would be grateful if you would speak to him personally. As you know I am trying to carry out your instructions and not Mr Madden's. ${ }^{42}$ [emphasis mine]

Rich's words suggest that there may have been an ongoing tension between Madden and Lingstrom about their respective responsibility and output for Children's Programmes. This is reinforced by a handwritten note stating, 'This serial is wandering all over the place. Is it planned?' This note is appended Tel. P.O, at that time Joanna Spicer, but not signed. Whomsoever it was addressed to, Madden responded: 'Children's Programmes really messed up Planning of this serial. [...] They don't seem to know or care for 'showmanship' or children's memories.' ${ }^{43}$ What was at stake here for Madden was not just children's memories and the effects interrupted scheduling might have on the loyalty of a child audience, but 'showmanship,' a concept which Madden later suggested was related to televisual spectacle, style and show business: 'We had the enthusiasm, therefore let us spend all the money that we had and do things in as big a way as we can, fast, so as to make an impact. [...] Television in those early days,' he concluded, perhaps especially in drama 'which was there all the way through,' 'was very firmly based on what we might call showbiz.' ${ }^{44}$

Madden's concept of drama seems, for better or worse, to have become entangled with 'show-biz' and its structures, and this is particularly true of Man in Armour. Madden's initial objections to the later series might have originated in its scheduling, which had some validity, but his criticisms, 'in sorrow, not anger', ${ }^{45}$ rapidly expanded to take in the management of its rights, credits, casting, times and scheduling; the entire production and the ethos in which it was produced, in fact. 


\section{Conclusions}

In Jason Jacobs' seminal reassessment of early television drama, he suggests that the 'development of television drama is not a story of the steady emancipation from theatrical values toward the cinematic, but one where producers were able to choose from a range of stylistic features, some of them associated with theatre, some with film styles, and some with the narrative forms of literature, such as the serialistic or the novel. ${ }^{46}$ This seems to have been an approach explicitly articulated and endorsed by Madden as early as 1948, and carrying through into his role as Head of Children's Programmes and a committed 'pioneer' of drama for children.

The aesthetics, form and production of Puck of Pook's Hill, Five Children and It and Man in Armour reflect Madden's articulation of television drama as a mixture of cinema, theatre and television, as well as his commitment to 'showmanship' as televisual spectacle. As archival research and his own testimony demonstrate, Madden's own conceptualisation of hybrid television drama, his particularised and 'pioneering' strategy of children's drama serial production, and his personal involvement in arranging drama schedules and productions, were highly influential within his brief tenure as Head of Department. Productions benefited from his experience and collaboration with light entertainment and theatre luminaries, which also influenced the forms and aesthetics of the drama produced under his administration. These theatrical influences and associations also contributed to the pioneering work Madden did in children's television drama and created dramatic forms and aesthetics that were notable for their early use of hybridity, showmanship and the spectacular. However, this involvement with light entertainment and theatre could potentially damage productions, as with Man in Armour, and might have been seen by the BBC as a conflict of interests for a post such as Head of Children's Programmes, contributing to Madden's subsequent replacement by Lingstrom.

Despite the ongoing production of serials of significant length and complexity after his departure from Children's Programmes, it is clear from Madden's interventions that he saw a great difference between the children's television that had been produced under his aegis and that of Lingstrom's. Madden bemoaned the lack of showmanship in children's television and saw children's television as a schedule which required the creation of space not perhaps of the theatre but of theatricality, an essential component of a drama production strategy of hybridity and spectacle. While Lingstrom has been regarded, and rightly so, as the architect of the BBC Children's Department, instituting its long-standing departmental philosophy and its developmental structure, the drama produced under Madden's administration forces a reappraisal of the forms, aesthetic and structure he brought to children's television drama.

\section{Acknowledgements}

This article is one of the outcomes of the research project 'Spaces of Television: Production, Site and Style,' funded by the Arts and Humanities Research Council [grant number AH/H018662] from 2010-2015 and based at the University of Reading. I gratefully acknowledge the assistance of the BBC Written Archive Centre, Caversham, for access to internal $B B C$ documents referred to here. 


\section{$\underline{\text { Notes }}$}

1 George Brandt, British Television Drama (Cambridge, 1981), 35.

2 John Caughie, 'Before the golden age: early television drama', in: John Corner (ed.), Popular Television in Britain (London, 1991), 25.

3 Memo, 'For the Children': Winter Plans 1948/49, Mary Adams to Norman Collins, 3 June 1948, BBC WAC T16/45/1.

4 See D. Buckingham, H. Davies, K. Jones and P. Kelley, Children's Television in Britain: history, discourse and policy (London, 1999).

5 Our Radio Critic, 'Children's Hour', The Manchester Guardian (1901-1959), 6 December 1950, 3.

6 Mark J. Docherty and Alistair D. McGown, The Hill and Beyond (London, 2003), 14. 7 Woman Aged 57 to run Junior TV, The Daily Express, 5 April 1951, 1.

8 Buckingham et al., op. cit., 18.

9 John Caughie, Television Drama: realism, modernism, and British culture (Oxford, 2000), 41.

10 Memo, Television Children's Programmes, Joanna Spicer to George Barnes, 15 January 1951 BBC WAC T16/45/1.

11 C. A. Lejeune, Television, The Observer 15 April 1951, 6.

12 Memo, Television Children's Programmes, Joanna Spicer to George Barnes, 15 January 1951 BBC WAC T16/45/1.

13 Document attached to memo between Spicer and Barnes of 15 January 1951 (as above), Television Children's Programmes: Answers to D.Tel.'s questions of 28 November, undated, BBC WAC T16/45/1. 14 Anna Home, Into the Box of Delights (London, 1993), 28.

15 Document attached to memo between Spicer and Barnes of 15 January 1951 (as above), Television Children's Programmes: Answers to D.Tel.'s questions of 28 November, undated, BBC WAC T16/45/1.

16 Jason Jacobs, The Intimate Screen: early British television drama (Oxford, 2000), 3. 17 Letter, Vere Shepstone to Matthew Forsyth, 7 March 1951, BBC WAC T2/ $129 / 1$.

18 Memo, Cecil Madden to Matthew Forsyth, 10 April 1951, BBC WAC T2/129/1. $19 \mathrm{lbid}$

20 Equipment list, undated, BBC WAC T2/129/1.

21 Memo, Matthew Forsyth to S. Mortimer, 3 September 1951, BBC WAC T2/ $129 / 2$.

22 Studio floor plans for tx 23 September, 7 and 9 October 1951, BBC WAC T2/ $129 / 2$.

23 Undated list of performers' fees, BBC WAC T2/129/1.

24 Undated telegram from Madden to Wood, BBC WAC T2/129/1.

25 Memo, Dorothea Brooking to Don Smith, 5 April 1951, BBC WAC T2/49.

26 Memo, unattributed, undated, BBC WAC T2/49.

27 Our Radio Critic, New Projects, The Manchester Guardian (1901-1959), 13 Jun 1951, 3.

28 Memo, Dorothea Brooking to Don Smith, 5 April 1951, BBC WAC T2/49.

29 Memo, Charles Gardner to Dorothea Brooking, undated, BBC WAC T2/49 
Charles Gardner was the reporter who gave a memorable if criticised live broadcast on the Battle of Britain in 1940: http://www.bbc.co.uk/archive/people/

52/68.shtml (accessed 29 January 2014).

30 Memo, Dorothea Brooking to Don Smith, 5 April 1951, BBC WAC T2/49.

31 Letter, Joseph Kirby (Kirby's Flying Ballets) to Dorothea Brooking, 12 April 1951, BBC WAC T2/49.

32 Furniture \& Property Requirements form, 26 May 1951 BBC WAC T2/49.

33 C.A. Lejeune, Television, The Observer, 4 March 1951, 6.

34 Memo, Children's Programmes, Joanna Spicer to George Barnes, 10 May 1951, BBC WAC T16/45/1.

35 Press release, undated, BBC WAC T2/95/2.

36 Memo, Sequence of Film for Man in Armour, No. 1, 20.09.52, Vivian Milroy

to Eddie Walstab, 17 September 1952, BBC WAC T2/95/2.

37 Furniture, Properties \& Drape Requirements form, 28 June 1954, BBC WAC

T2/95/2.

38 Ibid.

39 Memo, The Man in Armour [sic], Shaun Sutton to Jack Rich, 19 July 1954, BBC WAC T2/95/2.

40 From Our Radio Correspondent, New Transmitter for Third Programme, The Times, 6 April 1951, 7.

41 Memo, Bruce Gordon: The Man in Armour, Cecil Madden to Jack Rich, 26

August 1952, BBC WAC T2/95/2.

42 Memo, The Man in Armour: New series, Cecil Madden to Jack Rich, 15

September 1952, BBC T2/95/2.

43 Correspondence between Madden and (potentially) Joanna Spicer, undated, BBC $\mathrm{T} 2 / 95 / 2$.

44 Joan Bakewell and Nicholas Garnham, The New Priesthood (London, 1970), 9.

45 Handwritten annotation appended to memo, Man in Armour, Cecil Madden to Jack Rich, 22 September 1952, BBC WAC T2/95/2.

46 Jason Jacobs, The Intimate Screen (Oxford, 2000), 117.

Victoria Byard is a Ph.D. candidate at the University of Leicester. Her doctoral research is part of the AHRC-funded Spaces of Television project at the Universities of Reading, South Wales and Leicester, and looks at children's television fantasy drama between 1955 and 1994. She has also written about The Sarah Jane Adventures in J. Bignell and S. Lacey (eds), British Television Drama: past, present and future, 2nd edition (London, Palgrave Macmillan, forthcoming May 2014) and time travel in 1970s children's television for a forthcoming edited collection on Time Travel in the Media (edited by Joan Ormrod \& Matthew Jones, McFarland). 